\title{
The evaluation of local governance effectiveness in the selected cities of Czechia
}

\section{Lenka Hellebrandová*}

Charles University, Faculty of Science, Department of Social Geography and Regional Development, Czechia

* Corresponding author: lenka.hellebrandova@natur.cuni.cz

\begin{abstract}
The aim of this article is to measure the effectiveness of public administration by comparing long-term budget expenditures with goals specified in strategic documents of four cities from less developed regions in Czechia. The content analysis of strategic documents of these cities was carried out over the past 10 years. Next, the budget expenditure during the 2002-2017 period was analyzed and compared with goals specified in strategic plans of these cities. The results show the under-funding of the majority of the planned development goals.
\end{abstract}

\section{KEYWORDS}

local governance; effectiveness; self-government; local development; budget expenditure

Received: 5 March 2020

Accepted: 10 September 2020

Published online: 20 January 2021

Hellebrandová, L. (2021): The evaluation of local governance effectiveness in the selected cities of Czechia.

AUC Geographica 56(1), 18-30

https://doi.org/10.14712/23361980.2020.21

(C) 2021 The Author. This is an open-access article distributed under the terms of the Creative Commons Attribution License (http://creativecommons.org/licenses/by/4.0). 


\section{Introduction}

Over the course of the 1990s, the municipal level was strengthened while continuing territorial fragmentation resulted in the existence of over 6,250 municipalities, i.e. a relatively high number of elected local governments. This fact poses a number of problems especially in the financial area (i.e. an insufficiency of funds for larger investment projects in small municipalities). There are also problems associated with the exercise of public administration within the scope of delegated competencies at municipal level. The problem is that there are no precise boundaries between activities carried out by municipalities within self-government and the activities within state administration provided by municipalities, which also applies to the public funding of these activities. However, the role of local government for the development of the territory of the municipality or even the entire micro-region remains crucial. In this case, the role of larger cities (i.e. municipalities with extended powers) is important, although their potential as an initiator of local development has currently been utilized to a limited extent only.

With regard to their topicality, the matters of governance as an indispensable part of the exercise of public administration are at the heart of the interest of a number of scientific disciplines. Each such scientific discipline, either from the field of political science, sociology or economy, contributes to the research with its own theories and approaches (see Bovaird 2002). In Czechia, the matters of governance are addressed especially within the scope of political-science research (e.g. Jüptner et al. 2014), within the scope of public policy research (e.g. Potůček et al. 2005; Nekola 2004) and within the scope of sociology combined with political geography (e.g. Kostelecký, Patočková, Vobecká 2007). However, the geographic approach to governance studies is still very rare, although the interconnection of effectiveness with local development has political-geographical potential. An example of such geographical studies is the work of Rumpel, Slach, and Koutný (2013) focused on the process of urban shrinkage in Ostrava in the period 1990-2010. It is a shift from earlier studies of regionalization and administrative division of the state (e.g. Hampl, Ježek, Kühnl 1978; Hampl 1996).

In relation to governance, the growing demand for increasing the effectiveness and inspecting the activities of governments results from the ongoing changes in public administration (e.g. the introduction of the New Public Management methods), and it is also supported by the overall efforts of all public administration levels to reduce operating costs. Increasing the effectiveness and the quality of local governments was also the objective of various reforms of public administration (Silva and Buček 2017: 49). The problem is the fact that effectiveness may be perceived in various ways and its measurement is difficult in practice also with regard to the common unavailability of relevant data. Moreover, a number of activities of local governments are "non-profit" by their nature (e.g. provision of public services), so it is better to evaluate rather the fulfilment of long-term objectives than the economic performance.

The presented article aims to analyse the management of selected cities in terms of funding the development areas (policies) reflected in strategic documents. The assumption is that all the cities being analysed make active efforts to direct budgetary expenditures to the fields of local development. The comparative analysis of budgetary expenditures is to confirm or disprove this assumption. The result of the analysis will also provide information about the effectiveness of governance which, in geographical terms, will mean the existence or absence of support directed to the fields of local development. The subjects of comparison are the selected cities with the same input conditions, which are supposed to determine the real utilization of budgets.

\section{Governance and local democracy}

The basic preconditions of the existence of governance at a local or regional level is the decentralization and the creation of local self-government units. So governance may be regarded as one of the concepts of local democracy (Sisk 2001: 13). However, the problem is the non-existence of a uniform definition of the term "governance". The relatively frequently used concept of governance is the result of the functional shift in the perception of governance that is no longer connected only with the local government but also involves other actors (e.g. Bovaird and Löfflered 2003, Jüptner et al. 2014). According to Fukuyama (2013: 350 ), governance may be expressed as the ability of the government (either a democratic or non-democratic one) to create and subsequently enforce compliance with rules and the provision of services. Lynn, Heinrich, and Hill (2000) say governance is a legal framework and various aspects of governing associated, in particular, with the creation and provision of public goods and services. Human geography sees governance as the coordination within an organization (Gregory et al. ed. 2009: 213-313). Despite various concepts of governance, its basic characteristic is the involvement of multiple actors (and thus a larger complexity) but also greater opacity.

Potentially, due to territorial fragmentation, the exercise of local governance is in Czechia closer to citizens. However, given that the tools of direct democracy (local referendums, participatory budgeting) are used in Czechia only to a limited extent, the political power of citizens in relation to local governance is limited to the right to vote, in particular. However, it does not mean that the citizens do not have any influence on the political decisions of the local government. 
The development of interactions and communication within the scope of public administration is seen in practice e.g. in the form of meetings of political representatives with citizens or the engagement of citizens in the process of the planning of development and the provision of public services (see community forms of governance). What is also important is the inspectional role of citizens in relation to the local government and public authorities (e.g. Blakely and Leigh 2013). On the other hand, some experts (e.g. Swianiewicz ed. 2010) point out that territorial fragmentation on such a scale may hinder the enhancement of the effectiveness of the local governance.

Political geographers tend to study rather global governance and power disputes at the national level, but the local level of governance deserve their attention as well. It is possible to examine the effect of the environment on political decisions as well as the spatial changes and transformations of cities in the consequence of political decisions (e.g. analysis of shrinkage of the city of Ostrava in Rumpel and Slach 2012). Although the local level is influenced by globalization and by processes and decisions taken at higher hierarchy levels, the space where we live is still determined by the local government decisions. This assumption, namely that governance is regarded as an expression of executive power influencing the development of both the community and the territory, triggers the need to study local governance.

\subsection{Effectiveness and efficiency of governance and public administration}

The growing effort to measure the effectiveness and efficiency of governance results from the demand by the public as well as the public authorities themselves. The definition of efficiency and effectiveness is not so clear. In the case of efficiency, the emphasis is on reducing local spending. From the private sector perspective, efficiency is measured as the input to output ratio (e.g. Afonso, Schuknecht, Tanzi 2010; Kalb, Geys, Heinemann 2011). On the other hand, effectiveness means how the government achieves the policy goals (e.g. Worthington, Dollery 2000). This includes the evaluation the fulfillment of objectives with the lowest possible costs (e.g. Jüptner et al. 2014).

Most studies in the sphere of governance and public administration focus on measuring efficiency. Different approaches apply here, e.g. the cost-effectiveness method (e.g. Balaguer-Colla et al. 2019; Št'astná and Gregor 2011) or analyses efficiency in the provision of selected services and examine the effect of various factors. Geographic factors are of minor importance in the examination of the efficiency of governance - e.g. the study of Ermini and Santolini (2010) who used Italian examples to prove the effect of the deciding in neighbouring municipalities on the decisions of local politicians in the field of expenditures. As outputs, various analyses use indicators such as the number of lamps (for public lighting), total area (for infrastructure, parks, etc.) or, according to Kuhlmann (2010), the number and quality of administrative decisions as well. A disadvantage of this economic view of efficiency (measurement of inputs against outputs) is that it does not say anything about the quality of the service itself. The thing is that the perception of a service by the citizens is also very important. According to Potůček et al. (2005), political representatives find the results of interviewing respondents more helpful; in practice, such subjective measurements have the form of various satisfaction surveys carried out e.g. at municipal authorities. Although efficiency defined in this way allows the benchmarking of individual municipalities on the one hand, it often does not make it possible to explain the causes of the differences in efficiency on the other hand. An example of quite an extensive benchmarking at the level of municipalities with extended powers in Czechia is the study carried out by Št'astná and Gregor (2011).

Measuring the effectiveness of governance is not common due to the difficulty implementation in practice. The implementation of specific local policies is also influenced by factors that local governments can not change, but this should not be a reason to resign from measuring effectiveness. An example of this different approach is the work of Lankina, Hudalla, and Wollmann (2008), who evaluated local governance by analyzing the budgetary expenditures for the support of economic growth. Taking selected cities in Czechia as an example, the authors showed (p. 78-79) differences in both the budgetary expenditures and the implementation of long-term strategies. The cities also differed from one another in the ability to obtain grants or direct investments. Instead of effectiveness, many researchers focus rather on the quality of governance. But the quality (e.g. represented by transparency, openness) can be perceived as a part of the effectiveness measuring.

\subsection{Municipal budgeting as a tool of local development}

At all levels of public administration, budgeting is a political process (see Potůček et al. 2005) in which the interests of all the political actors are naturally reflected. Budgets should respect predefined objectives and priorities. In terms of local development, such objectives should be based on the adopted strategic documents so as to contribute to the solving of long-term problems and the local development. In this case, we consider specific local development policies in selected cities (LAU in NUTS classification) with potential extension to the regions of municipalities with extended power. For the Ministry of the Interior, these regions are considered as a cornerstone of the current territorial division of the state.

The budget breakdown (classification of revenues and expenditures) is set out in Regulation of the 
Ministry of Finance No. 323/2002 Coll. As a preliminary point it should be noted that there are two types of budgets: (1) a current budget to fund public services and goods; (2) a capital budget to fund investments. The structure of a capital budget is influenced to a certain extent by the municipality's ability to draw grants from various sources (EU, ministries, regions, etc.) and there may be large differences in the amount of total investments from year to year. The existence of a uniform budget breakdown is a necessary precondition for analysing the management of municipalities and for their benchmarking.

What is of key importance for studying the effectiveness of governance is the expenditures within the scope of self-government competencies (see Act No. $128 / 2000$ Coll.), because the local government must find a compromise between its interests, the interests of the other actors and the funds available in the budget. Moreover, the competencies of municipalities and the requirements for their activities change over the course of time, e.g. after districts were cancelled, the vast majority of their competencies was not transferred to the newly established regions but to the municipalities (Hemmings 2006: 6-7). The fields funded within the scope of self-government competencies include: (1) education; (2) housing; (3) transport; (4) culture and recreation; (5) security; (6) social care; (7) health care; (8) other public services; (9) land use planning. Although the provision of basic public services is perceived very sensitively by the inhabitants of the given municipality and is often used as one of the governance evaluation criteria (e.g. Bovaird and Löffler 2003), the non-existence of any standards of public service availability does not place any greater demands on the local government for securing the necessary services. Despite that, as pointed out by Plaček et al. (2016: 5-6), capital expenditures, in particular, are one of the tools for municipal politicians to gain the favour of their electors.

\section{Methodology}

The methodological procedures and data sources used in this research reflect the set objective, i.e. evaluation of the effectiveness of governance in 4 selected cities in Czechia. Although data on the management of municipalities are relatively well accessible in the databases of the Ministry of Finance, they have their limitations, so data obtained directly from municipal authorities under Act No. 106/1999 Coll., on free access to information, were also used.

\subsection{Effectiveness}

To evaluate effectiveness, this analysis compared the current and capital expenditures directed in the period 2002-2017 to the predefined development policies with the representation of such policies in the strategic documents of cities.

If confronting the fields of funding within the scope of self-government activities with the basic fields of support of local development (according to Blakely and Leigh 2013), we can set out the development fields to which "spare" funds within the scope of the budget, in particular, should be directed as a matter of priority: (1) support of entrepreneurship; (2) human resources (education, research and development, employment); and (3) strategic planning. These development areas should also be naturally reflected in the strategic documents of the cities concerned. Definition of the development policies pursued at the local level was based on the national strategies and reflected the obligations of municipalities within the scope of self-government under Act No. 128/2000 Coll., on municipalities. Contrary to the definition of such policies at the national level, their definition at the level of municipalities has a much narrower focus. In total, expenditures in 6 development policies (Table 1) were studied. When analysing the expenditures in the field of social prevention services, subdivision 437 covering a total of 9 sections (according to Regulation of the Ministry of Finance No. 323/2002) was studied in the budgets.

With regard to the nature of development fields, varied amounts of expenditures (capital ones, in particular) may be expected. Large infrastructure projects in the environmental field constitute higher budgetary items than e.g. educational projects in the social field. The total budgetary expenditures are, however, only one of the indicators; it is important whether funds are directed to development policies at all and whether it is a long-term trend. Although the proportion of capital expenditures to the total expenditures was growing in general until the economic crisis in 2009 , this was followed by a trend of reducing investments (Zdražil 2019: 381).

\subsection{Data sources and data processing}

In the first phase of the research, the contents of strategic documents of all the examined cities were analysed. These strategic documents are generally drawn up for a multiannual period and their updating is not exceptional, so the analysis of the contents also included their updated versions. All the documents were obtained from the websites of the examined cities. As part of the content analysis, the presence of keywords and key phrases for the given development policy in strategic documents was examined. The result was either YES if the keywords appeared in the document, or NO if they were not present in the document. Methodologically, a quantitative content analysis was used (Hendl 2008: 388). In terms of topics or the nature of the development documents, the analysed cases included both quite general strategic documents and thematically narrower strategies 
Tab. 1 Local development policies in relation to municipal budgets.

\begin{tabular}{|c|c|c|}
\hline \multicolumn{2}{|c|}{ Development policy } & Budget item analyzed \\
\hline \multicolumn{2}{|c|}{ Environmental policy } & $37 x x, 23 x x$ \\
\hline \multicolumn{2}{|c|}{$\begin{array}{l}\text { Research, development } \\
\text { and innovation policy }\end{array}$} & $2125, x \times x 8$ \\
\hline \multicolumn{2}{|c|}{ Employment policy } & $422 x$ \\
\hline \multicolumn{2}{|c|}{ Economic policy } & 2123, 2124, 2131, 2139 \\
\hline \multirow{2}{*}{$\begin{array}{l}\text { Social } \\
\text { policy }\end{array}$} & Education policy & $\begin{array}{l}\text { 31xx, 32xx (under current } \\
\text { expenditure only items 3212, } \\
3292,3293 \text { ) }\end{array}$ \\
\hline & $\begin{array}{l}\text { Policy of combating } \\
\text { poverty and social exclusion }\end{array}$ & $\begin{array}{l}3421,437 x \text { (under current } \\
\text { expenditure in addition item } \\
4342 \text { ) }\end{array}$ \\
\hline
\end{tabular}

Source: Author

focused e.g. on the field of social inclusion (see Appendix 1). There were also community plans of social services, which constitute an illustrative example of the application of new forms of political decision-making at the local level. In order to compare the examined cities, the analysis used the overall percentage of the representation of the development policies (i.e. in how many documents the given development policy was represented) in all types of strategic documents.

In the field of budgeting the examined cities, the main data source was the web application "Monitor" administered by the Ministry of Finance (from 2013) or its preceding version "ÚFIS" (from 2010 to 2012) and "ARISweb" (until 2009). As another source, the analysis used the economic results for individual years published on the websites of the concerned cities. The reason for the use of multiple sources concerning the management of examined cities is a certain error rate of the data obtained from the Ministry of Finance. A problem is that in practice it happens sometimes that municipalities assign expenditures to incorrect budget items, so it is necessary to compare the data from the Ministry of Finance with the data from the municipalities regarding certain items. The incorrectly assigned items were mechanically added to the correct ones afterwards. The analysis always used the economic results for the given year. The assignment of individual budget items to the given type of development policies (Table 1) is based on the description of the budget items (see Regulation of the Ministry of Finance No. 323/2002 Coll.) as well as on the findings derived from formerly conducted analyses.

\subsection{Selection of cases}

In practice, the support of local development is more often discussed with respect to problematic regions, which this analysis is focused on. To comply with the condition of identical entry socioeconomic conditions, the examined cities were selected from the regions that have ranked among the problematic ones over a long period, especially for the following reasons: they are mostly (1) economically weak and structurally affected regions (e.g. with a higher unemployment rate and a specific economic structure); (2) regions with a low level of social capital (Kostelecký, Patočková, Vobecká 2007: 926) and a larger number of inhabitants at the risk of social exclusion (Ministry of Labour and Social Affairs 2006); (3) regions with problematic drawing of EU funds, which resulted in a number of local political conflicts.

A total of four cities, of which three (Chomutov, Most and Děčín) are located in the Ústí Region and one (Sokolov) in the Karlovy Vary Region, were selected for the analysis. The cities Chomutov, Most and Děčín have comparable populations and are in the same category in terms of the budgetary allocation of taxes (RUD). Sokolov is one category lower. Classification in RUD categories defines the amount of the tax revenues (which form the largest part of the overall revenues) and thus the amount of the budget. All the analysed cities showed a high unemployment rate over a long period and their territories included at least two socially excluded locations according to the results of a mapping in 2006 (Ministry of Labour and Social Affairs 2006). All the cities are also municipalities with extended powers, so they have a better institutional background (represented by a municipal authority), so also a greater capacity to systematically solve long-term problems. The inclusion of Sokolov, which has a lower budget (its total revenues are approximately CZK 600 million as compared to CZK 1 billion in Chomutov), and the comparison of its approach to local development with the approach of other cities is expected to shed light on the extent to which the amount of the budget is a limiting factor for the development of cities.

\section{Management of cities and financing of development policies}

As part of the analysis, both the management within the current expenditures and the management of capital expenditures were examined. Long-term trends in the management of municipalities are naturally subject to external economic and political influences. An example is the economic crisis in 2009, which resulted in an increase in the unemployment rate and a subsequent increase of expenditures for the active employment policy, or changes in the investment behaviour due to the changes of local governments after municipal elections. We also must not disregard the role of the European funds, as the period under analysis largely overlaps with two programme periods (2007-2013 and 2014-2020).

So what has the greatest influence on the structure of expenditures? Where current expenditures are concerned, these are the expenditures for the salaries of the employees of authorities and organizations established by the city, and the expenditures for the 


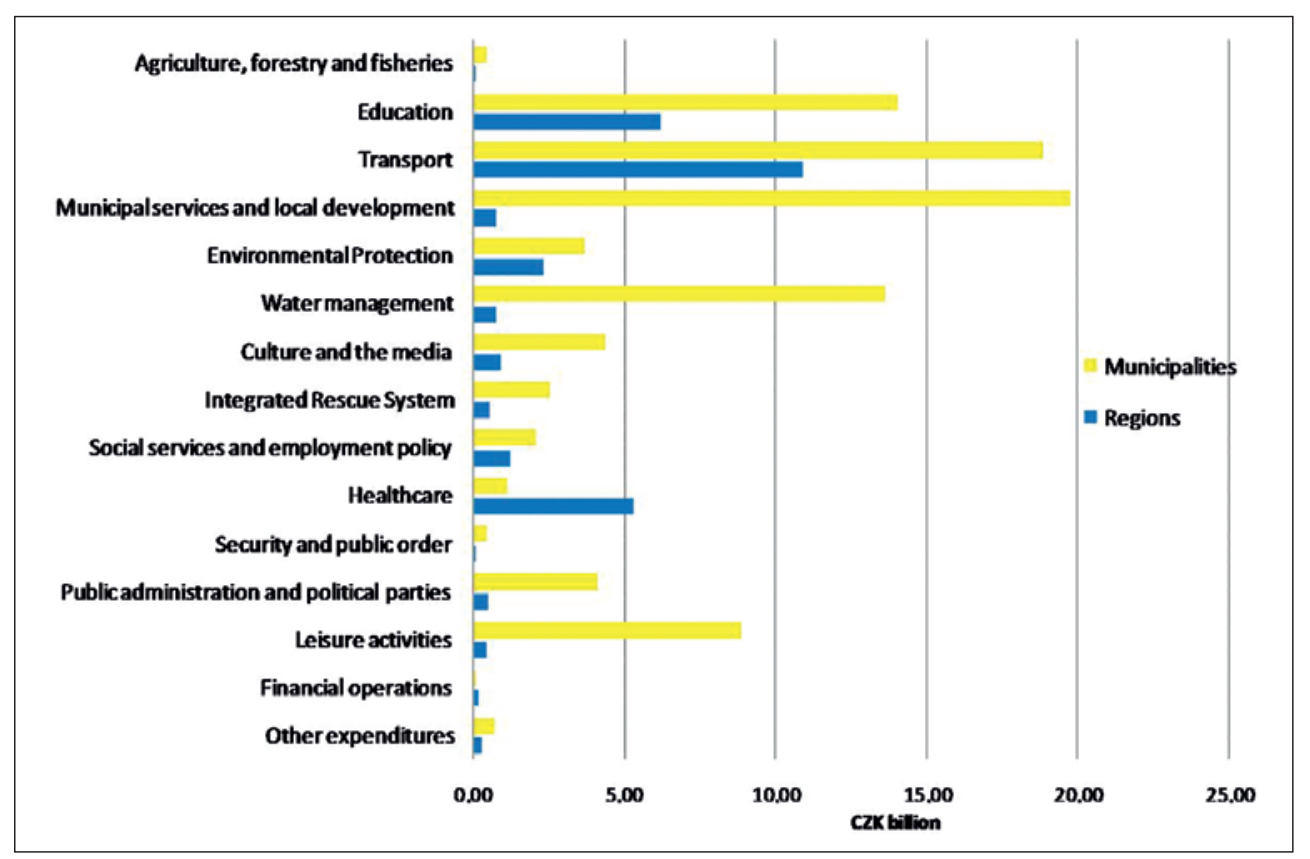

Fig. 1 Structure of capital expenditure by municipalities and regions in Czechia in 2018. Source: Author

operation and maintenance of buildings and other facilities. It is important to note that the amount of expenditures for the salaries of public service employees is largely covered by transfers from the state budget. In terms of capital expenditures, the most significant investments usually go to the field of housing and municipal services (Figure 1), transport and education. The significance of these investments is reflected in the fact that all these fields fall within the scope of self-government competences (Ministry of the Interior 2019: 77).

The main characteristic of capital expenditures is their limited amount. In practice, the tendency is to utilize available grants, including possible funding of investment projects from EU funds (see an example of Ostrava city in Rumpel and Slach 2012). However, the availability of grants should not be the main factor influencing investment behaviour, because the published calls for applications for grants do not always correspond to the particular needs of municipalities. From the perspective of the national level (Ministry for Regional Development 2017: 20) it is crucial that the public administration supports the involvement of all stakeholders in the process of strategic planning.

For each of the development policies, the expenditures (current and capital ones) for the entire examined period (2002-2017) are added up and their percentage in the total expenditures is calculated. In the table below (Table 2), the expenditures are confronted with the significance (expressed as a percentage) of development policies in the strategic documents. In this research, we consider the local governance effective if meets the requirements for securing local development.
As discussed above, a relatively high amount of funds towards the field of environmental and education policy was co-financed from EU funds. An overview of the most expensive investment projects (Table 3) illustrates well the level of use and purpose of EU funds. Very high investments were directed in sports facilities, not all of which serve the general public (e.g. differences between ice hockey stadium and swimming pool). From the local government perspective, the budgetary priority was given to big infrastructure projects like the revitalization of the city centers or traffic construction. On the one hand, many of these projects would not be implemented without EU co-financing, on the other hand, they are not priorities from strategic documents.

The content analysis of strategic documents showed small differences in local government priorities. All analyzed cities put great emphasis on the field of combating poverty and social exclusion, education, and employment (Figure 2). The result of the Analysis of Socially Excluded Locations (Ministry of Labour and Social Affairs 2006: 74) identified high unemployment as a big problem in these localities. The policy of combating poverty and social exclusion is more discussed in the partial chapter. On the contrary, only Chomutov and Most focused their strategic documents on the field of research, development, and innovations. It must be emphasized that all the cities are located in structurally affected regions where the efforts to develop a high-tech industry and innovation environment have not been very successful so far, even with the use of money from EU funds (Hána and Hellebrandová 2018). The support for this field should be one of the priorities of local governments. 
Tab. 2 Comparison of expenditure on local development policies, 2002-2017.

\begin{tabular}{|c|c|c|c|c|}
\hline $\begin{array}{l}\text { Development } \\
\text { policy }\end{array}$ & City & $\begin{array}{l}\text { Representation of } \\
\text { development policies in } \\
\text { strategic documents (\%) }\end{array}$ & $\begin{array}{l}\text { The share of current } \\
\text { expenditure 2002-2017 } \\
\text { (\%) }\end{array}$ & $\begin{array}{c}\text { The share of capital } \\
\text { expenditure, 2002-2017 } \\
\text { (\%) }\end{array}$ \\
\hline \multirow{4}{*}{$\begin{array}{l}\text { Environmental } \\
\text { policy }\end{array}$} & Děčín & 8.00 & - & 8.52 \\
\hline & Chomutov & 14.00 & - & 3.44 \\
\hline & Most & 17.00 & - & 6.62 \\
\hline & Sokolov & 8.00 & - & 7.38 \\
\hline \multirow{4}{*}{$\begin{array}{l}\text { Research, development } \\
\text { and innovation policy }\end{array}$} & Děčín & 0.00 & 0.00 & 0.00 \\
\hline & Chomutov & 7.00 & 0.00 & 0.00 \\
\hline & Most & 5.00 & 0.00 & 0.00 \\
\hline & Sokolov & 0.00 & 0.00 & 0.00 \\
\hline \multirow{4}{*}{$\begin{array}{l}\text { Employment } \\
\text { policy }\end{array}$} & Děčín & 23.00 & 0.00 & 0.00 \\
\hline & Chomutov & 22.00 & 1.22 & 0.01 \\
\hline & Most & 17.00 & 0.09 & 0.00 \\
\hline & Sokolov & 23.00 & 0.00 & 0.00 \\
\hline \multirow{4}{*}{$\begin{array}{l}\text { Economic } \\
\text { policy }\end{array}$} & Děčín & 15.00 & 0.00 & 0.00 \\
\hline & Chomutov & 7.00 & 0.00 & 0.00 \\
\hline & Most & 11.00 & $<0.01$ & 0.00 \\
\hline & Sokolov & 8.00 & 0.00 & 0.00 \\
\hline \multirow{4}{*}{$\begin{array}{l}\text { Education } \\
\text { policy }\end{array}$} & Děčín & 23.00 & 0.00 & 7.34 \\
\hline & Chomutov & 22.00 & 0.03 & 4.23 \\
\hline & Most & 22.00 & 0.10 & 7.03 \\
\hline & Sokolov & 15.00 & 0.00 & 10.71 \\
\hline \multirow{4}{*}{$\begin{array}{l}\text { Policy of combating } \\
\text { poverty and social } \\
\text { exclusion }\end{array}$} & Děčín & 23.00 & 0.62 & 0.23 \\
\hline & Chomutov & 21.00 & 0.11 & $<0.01$ \\
\hline & Most & 22.00 & 0.90 & 5.15 \\
\hline & Sokolov & 38.00 & 0.97 & 1.30 \\
\hline
\end{tabular}

Source: Author

At the same time, this field requires a certain degree of cooperation between stakeholders at various territorial levels - from the state agencies (e.g. CzechInvest) through the regional level to the local level represented by the examined cities. However, neither current nor capital expenditures were directed to this field in any of the analyzed cities.

In terms of strategic plans, environmental policy was given greater attention in Most and Chomutov.
Problems associated with a lower quality of the environment and with environmental burdens have been one of the main limitations of development of the Ústí Region (and partially the Karlovy Vary Region) over a long period. In particular, this policy was long funded with support from EU funds. When considering absolute amounts, the highest amount was invested in this field by Most (over CZK 273 million), but when considering their proportion to the total

Tab. 3 The most significant investments from EU funds, 2005-2017.

\begin{tabular}{|l|}
\hline Děčín \\
revitalization of a brownfield in the city center into a library and \\
multimedia center over CZK 119 million \\
a reconstruction of schools and their sports grounds over CZK 60 million \\
reconstruction of the retirement home over CZK 40 million \\
extension of the swimming area over CZK 39 million \\
Most \\
\hline reconstruction of schools over CZK 50 million \\
- transport infrastructure projects (stations etc.) over CZK 40 million \\
20 million
\end{tabular}

Source: Ministry for Regional Development 2020

\section{Chomutov}

- sports fields projects (athletic stadium, winter stadium) over CZK 800 million

- landfill reclamation over CZK 40 million

- complex revitalization of housing estates over CZK 40 million Sokolov

- reconstruction of the winter stadium over CZK 110 million

n wastewater treatment maters over CZK 51 million

- revitalization of the city swimming pool over CZK 42 million

another sports fields projects over CZK 40 million 


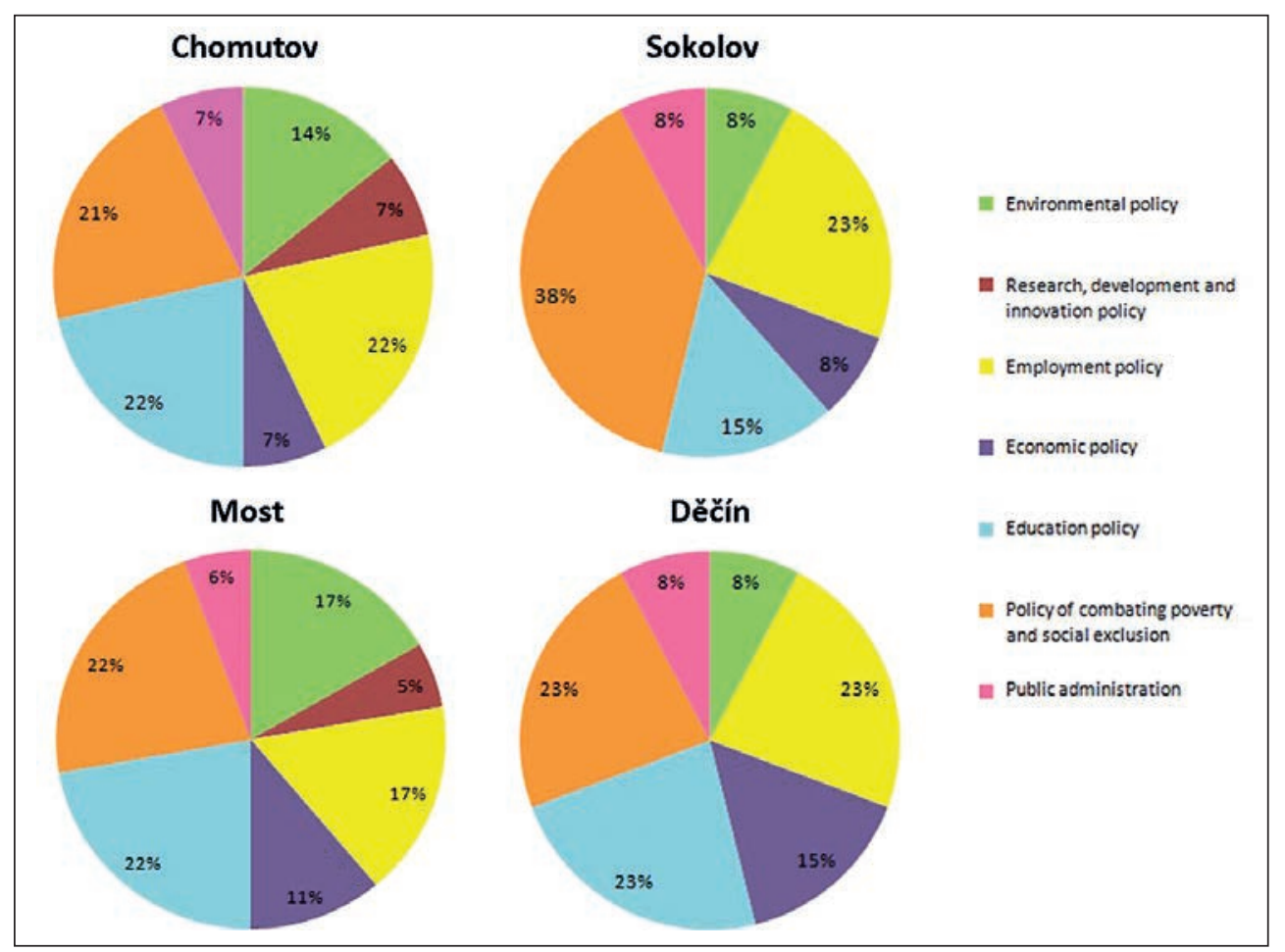

Fig. 2 a-d Representation of development policies in strategic documents of the cities of Chomutov, Sokolov, Most and Děčín. Source: Author

investments, such investments were more significant in Děčín (approximately 8.5\%) and Sokolov (approximately 7.4\%). In Chomutov, the proportion of such expenditures is only $3.4 \%$, but in absolute terms it is more than CZK 150 million. The environmental field includes investments e.g. in the revitalization of urban vegetation, landfilling, wastewater treatment matters and, in Děčín, safety measures to address the risk of rockslides along the Elbe river. Although the environment is an area that EU funds have also significantly helped to improve, in the future, at least Most will have to respond to the end of lignite mining.

Like environmental policy, education was a key part of strategic plans. With respect to current expenditures, the field of the education policy is defined only as the support for university activities, including research and development at university institutions, and multicultural education and education events focused on the integration of disadvantaged groups of the population. The matters of the integration of disadvantaged groups are often addressed and financially supported by non-profit organizations rather than by the cities themselves. The only cities of the analysed ones that directed expenditures to this field were Chomutov and Most. As for Chomutov, the aggregate expenditures for the entire period amounted to approximately CZK 4 million $(0.03 \%$ of the total current expenditures), while the expenditures of Most amounted to CZK 16 million $(0.1 \%$ of the total current expenditures). In both cities, $100 \%$ of such expenditures consisted of expenditures for the support of universities and research and development.

For Chomutov, Most and Sokolov, the education policy is a field to which these cities directed most of their capital expenditures. The total amount of investments in this field ranges from CZK 167 million (Děčín) to CZK 290 million (Most). The proportion of such expenditures to the total investments was highest in Sokolov (10.7\%), slightly lower in Děčín and Most (7\%) and lowest in Chomutov (4\%). With the use of such expenditures, many investment projects (co-financed from EU funds) were completed, such as the renovation of school buildings and the purchase of classroom equipment in order to enhance the quality of education. Unlike the current expenditures, which also partially include educational projects, the investments serve to improve the "infrastructure". Both these groups of expenditures supplement each other and must be mutually interconnected in order to enhance the quality of education. The field of education policy illustrates well the difficulties in measuring its efficiency (from an economic point of view). We can relate the invested funds to the number of pupils, but it is not possible to say simply that more funding per pupil is (in)efficient. On the other hand, the reconstruction of the school playground and making it available to the general public (e.g. the long-term policy applied in Most) can be considered as effective.

Employment policy was the second or third most important topic in the content of strategic documents. Despite this, only two cities - Chomutov and 
Most directed current expenditures to this field. Both the cities differ considerably in both the absolute amounts and their relative proportions. The expenditures of Chomutov amounted to more than CZK 150 million while the expenditures of Most amounted to CZK 15 million for the entire examined period. The funding of this field was stable in both the cities throughout the period, except that in certain sub-periods different forms of employment support were preferred (socially purposeful jobs, etc.). Although the cities are located in a structurally affected region, the current unemployment rate is low, in January 2019 it was 5.8\% (Chomutov) and 6.1\% (Most). The fact that not all the cities funded this field demonstrates a certain inconsistency with the analysed strategic documents, as the field of employment ranked among the most frequently represented ones, even in Sokolov and Děčín.

The economic policy is a specific development field that is relatively harder to examine and that includes the support of industrial zone development, the enhancement of industry competitiveness and the support of entrepreneurship. Industrial zones, their construction and development, in particular, are supported quite considerably by some of the cities (similar to Ostrava, see Rumpel and Slach 2012: 122). This mostly concerns the industrial zones in the territory of the cities, but many large and development industrial zones are also located along the main traffic routes and are co-funded by the state and regions as well. Regrettably, the expenditures of the cities directed to the construction of industrial zones (e.g. construction of the infrastructure) are often included and distributed in other budget items (e.g. under transport expenditures), so they cannot be precisely quantified. Current expenditures in the economic policy were only seen in the budgetary items of Most, namely in the amount of less than CZK 0.5 million. It is a negligible percentage of the total expenditures. These expenditures are disproportionate to the importance of this policy in the strategic documents.

\subsection{Policy of combating poverty and social exclusion}

Currently, the principles of community planning are applied in solving the problems of social exclusion at the same time they contribute to the development of representative democracy in a broader context. As stated by Bovaird (2007: 846), politicians should try to find ways to connect service providers and users. Community planning may also help prevent social exclusion if implemented in the field of social services (Ministry of Labour and Social Affairs 2006). The analysis of the strategic documents confirmed that in all the community plans of development of social services, the topic of social exclusion and combating it was in the spotlight (Figure 1). Other policies mentioned and associated with community planning were the fields of employment and education. For comparison, it is possible to state the results of a formerly conducted research among mayors and city representatives in European countries, where Czechia, just like e.g. France, did not place any emphasis on combating social exclusion (see Getimis and Magnier 2013: 240).

The policy of combating poverty and social exclusion is the most significant development policy in terms of current expenditures. All the examined cities directed less than $1 \%$ of the total current

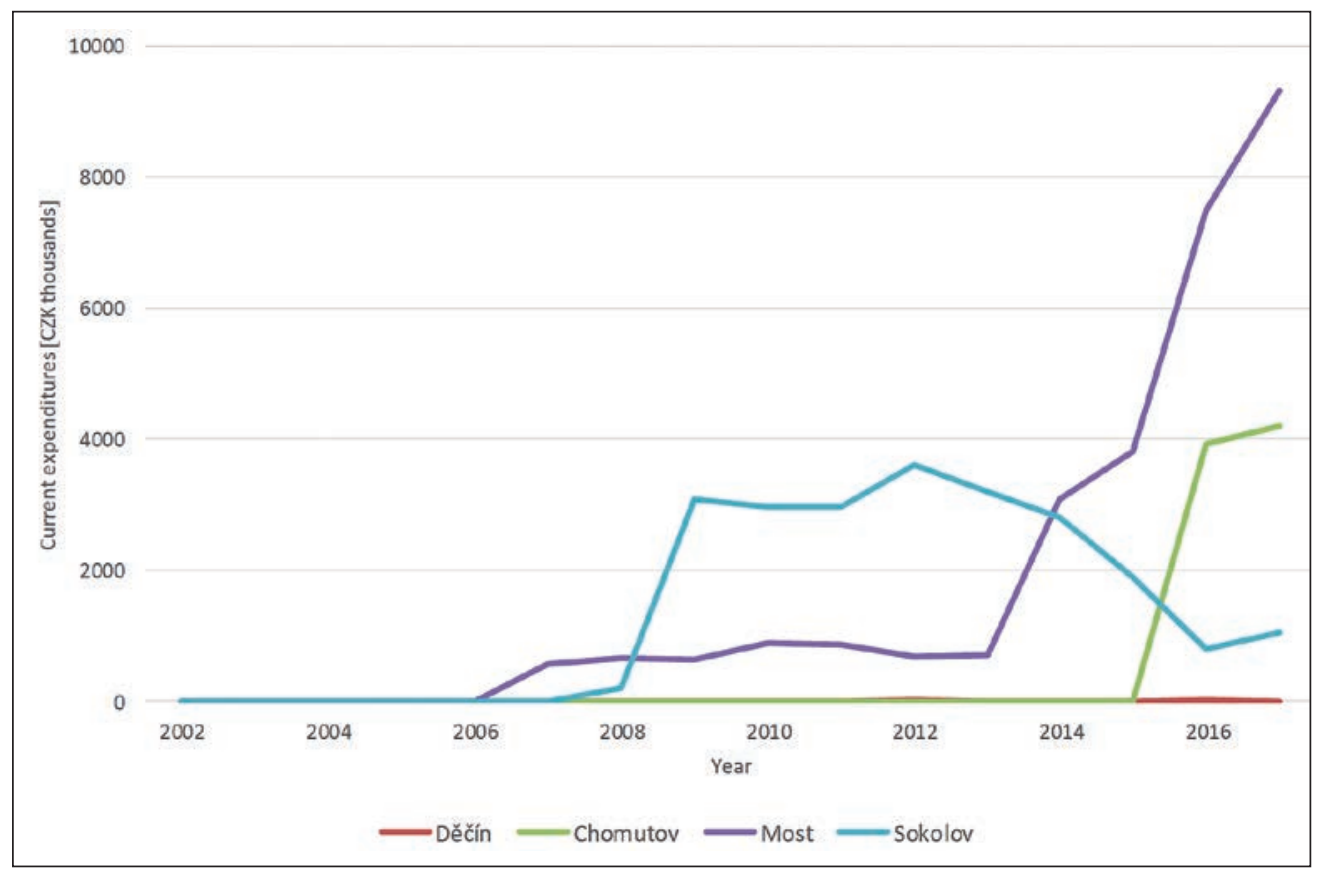

Fig. 3 Current expenditure on social prevention. Source: Author 


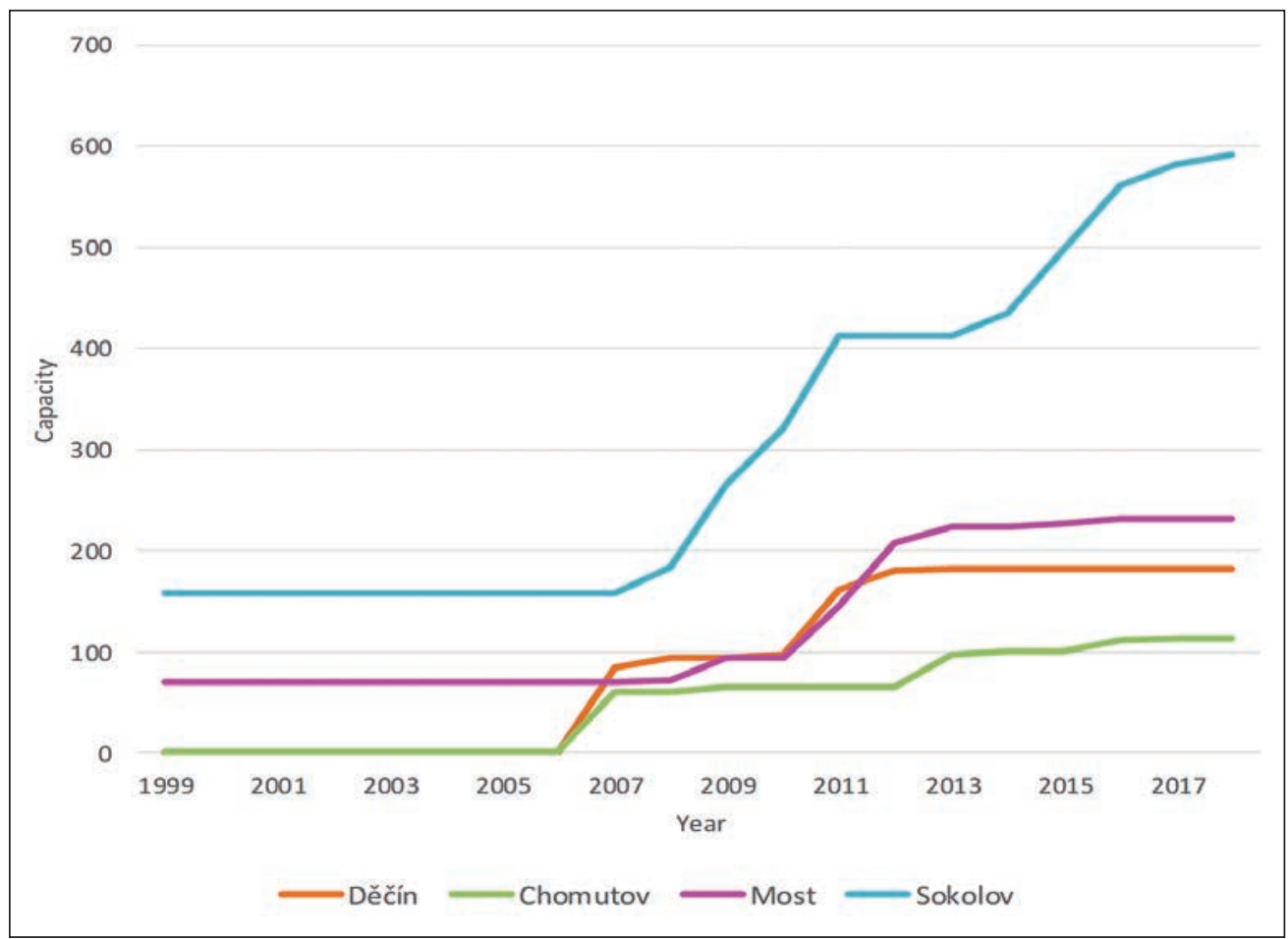

Fig. 4 Capacity of places in social prevention facilities.

Source: Author

expenditures to this field. In absolute terms, the highest amount (approximately CZK 148 million) for the analysed period was directed to this field by Most. The expenditures of the other cities are one order of magnitude lower. The capital expenditures were invested in leisure time activities of children and youth and in strengthening the capacity of social prevention services, e.g. in the purchase of equipment of low-threshold facilities for children and youth. The support for leisure time activities, no matter whether provided under the umbrella of institutions or whether provided through the extension of opportunities in the form of building sports ground, is supposed to serve to prevent social pathologies.

Social prevention as a part of this policy was summarized in two analyses (dated 2006 and 2015) from the Ministry of Labour and Social Affairs. The analysis carried out in 2015 (Ministry of Labour and Social Affairs 2015: 84) points out that social prevention services are distributed unevenly at the level of municipalities with extended powers, so they do not fully reflect the needs of inhabitants of socially excluded locations. In this context, their current distribution is partially a result of a response to the socioeconomic development and partially a result of an active approach of local authorities. It should be noted that in practice there are also situations where the most deprived areas are not targeted by programmes, because priority is given to those areas where results may be achieved faster and cheaper (Atkinson 2000).

As for the expenditures in the field of social prevention, the measurement of effectiveness in terms of long-term impacts is very difficult. It can be expected that any greater effects brought about by these expenditures will only appear in the longer term. On the other hand, it is possible to analyse e.g. the degree of the provision of social prevention services. Such facilities include low-threshold facilities for children and youth, field services, expert social consultancy, shelters and halfway houses and other special social services (social rehabilitation, etc.). In absolute terms, the highest growth of (weekly) capacities for the entire examined period was seen in Sokolov (Figure 4) where the capacities of facilities increased four times over 10 years. In Děčín and Most, the greatest extension of the capacities of social prevention facilities took place in the period from 2007 to 2012 . Chomutov has the lowest capacities (114 clients).

The first budgetary expenditures in social prevention in Most appeared in 2007, in Sokolov in 2008, in Děčín in 2012, and in Chomutov in 2016 (Figure $3)$. In contrast to the increasing offer and capacity of services in this field, the current expenditures have gradually grown only in Most and Chomutov in recent years. Děčín funded this field only in 2012 and 2016 in amounts not exceeding tens of thousands of CZK per year.

\section{Summary}

As discussed in the theoretical introductory part of this article, several methods are used in practice to measure effectiveness. In this research, such governance 
that meets the requirements for securing local development is considered effective. In particular, this concerns addressing long-term problems emphasized in various types of strategic documents adopted in the cities in the course of several years. A basic assumption is that the local governments reflect the objectives set out in the strategic documents (despite the fact that they are not binding and legally enforceable) in their decision-making associated with the budget. In practice, expenditures should be directed more frequently and regularly to the fields most frequently mentioned in the strategic documents. So the objective was to compare the effectiveness of governance of the four examined cities and to determine which of them support local development systematically.

The analysis of the expenditure parts of budgets of the examined cities showed considerable differences in the priorities of individual local governments. While the proportion of "development" current expenditures to the total current expenditures was negligible, the situation differed for capital expenditures. The reason is a smaller overall volume of the capital budget, so any quite a large investment results in a higher proportion of the given development area to the total capital expenditures. In terms of absolute amounts, the most funds were directed to the education policy, closely followed by the environment. These total expenditures in individual development policies and their relative proportions tothe total expenditures may be compared with the representation of such development policies in the strategic documents to indicate the (non-)effectiveness of the local governments.

As the first one, we can compare the expenditures in the field of combating poverty and social exclusion, which is the policy that is most frequently represented in the strategic documents in all the examined cities. All the cities directed expenditures to this field, but only in Sokolov and Most did such expenditures amount to at least $1 \%$ of the total expenditures, and this percentage is even higher in capital expenditures. The effort to actively address the matters of social exclusionin these cities may also be proved by the growth of capacities of social prevention facilities throughout the examined period.

Another key development policy frequently mentioned in the development documents is the field of employment. However, its significance in the strategic documents does not correspond to its representation in the expenditure parts of the current and capital budgets of the examined cities. Two cities (Děčín and Sokolov) even had zero expenditures in this field. As for the capital budget, any greater expenditures may not be expected, because the employment policy is covered from current expenditures. Like many other policies, the employment policy is strongly influenced by the setting of its support at the national level, although, as a matter of course, the municipalities are free to use their own initiative.
The field of education is considered in the budgets much more than the employment policy. As for the current expenditures, the amounts are minimal, but as for the capital expenditures, their proportion is relatively high in all the cities, ranging from 4 to $10 \%$. The support for the education policy largely consists of investments in the buildings and the purchase of equipment. However, improving the quality of infrastructure is only one of the conditions for improving the quality of education. To achieve improvement, this form of investments must be supplemented by investments in "soft" (i.e. education) projects. In this development policy, governments are effective, i.e. show the efforts to fund this field systematically and on a long-term basis.

These three development policies make it possible to compare the cities and their use of current and capital budgets in the best manner. In general, the degree of representation of various development policies in the strategic documents does not correspond much to their percentage in the budgetary expenditures. The fields of the environment and education can be identified as the development policies most supported by capital expenditures. In both these fields, investments co-funded from EU funds have a role that cannot be ignored. So it is unclear whether the local governments really want to solve long-term problems or whether they primarily use the available financial sources regardless of the necessity of the given investment.

\section{Conclusion}

The objective of this article is to show one of the possible approaches to measuring effectiveness, namely the comparison of the long-term trends in budgetary expenditures with the "trends" in the strategic documents. It was assumed that all the examined cities represented by their local governments would show efforts to address problematic fields and fund selected development fields on a long-term basis.

The presented analysis of the budget expenditure of four selected cities revealed an insufficient degree of funding of a majority of the defined development policies. Although a number of strategic documents emphasizing various types of policies were drawn up, in fact only the fields of the environment and education and, to a considerably lower extent, the field of combating poverty and social exclusion experienced a certain development. By contrast, e.g. support for innovations, research and development was not reflected in the expenditures at all. So the effectiveness of governance within the meaning of the fulfilment of long-term objectives in the field of local development cannot be evaluated positively in the analysed cities.

In addition to the priorities of various governments and the necessity to respond to current problems and 
challenges, some other influences are also reflected in the budgetary behaviour. The higher percentage of certain types of expenditures (investments, in particular) that were co-funded from other sources (predominantly grants from EU funds) may reflect the efforts of local governments to utilize available grants with a lower emphasis on their development potential. Moreover, the implementation of large investment projects requires more time for the preparation of all the necessary documents, so priority is naturally given to formerly prepared projects as long as funds are available for the implementation. In the future, the analysed cities should focus more on the fulfilment of strategic documents and on the addressing of longterm problems and should try to lower its dependence on various grants from external sources.

The reason to keep paying attention to this category of cities is their role in the local development that cannot be ignored. Given the size of their budgets that make it possible to implement multiple costly projects, their activities have an effect on the other municipalities in the entire micro-region. The transfer of competencies to the local level on the principle of subsidiarity was associated with the expectations that this category of cities would be an initiator of development activities. However, this article shows certain pitfalls in the form of problems with the fulfilment of own strategic and development objectives. It remains unclear whether cities will manage to meet expectations and will become not only the key actors of local development but also partners for other municipalities in the micro-region. For political geographers, this topic constitutes potential for further research of public administration and governance in the Czech context.

\section{Acknowledgements}

This research was supported by the Charles University under SVV (grant number 260566). The author would further like to thank David Hána for his valuable comments on the draft version of the article.

\section{References}

Afonso, A., Schuknecht, L., Tanzi, V. (2010): Public sector efficiency: evidence for new EU member states and emerging markets. Applied Economics 42(17), 2147-2164, https://doi.org/10.1080 /00036840701765460.

Atkinson, R. (2000): Combating social exclusion in Europe: the new urban policy challenge. Urban Studies 37(5-6), 1037-1055, https://doi.org/10.1080 /00420980050011226.

Balaguer-Coll, M. T. et al. (2019): Local government efficiency: determinants and spatial interdependence. Applied Economics 51(14), 1478-1494, https://doi.org /10.1080/00036846.2018.1527458.
Blakely, E. J., Leigh, N. G. (2013): Planning local economic development: theory and practice. USA: Sage Publications.

Bovaird, T. (2002): Public Management and Governance: EmergingTrends and Potencial Future Directions. In Vigoda-Gadot, E., ed.: Public Administration: An interdisciplinary Critical analysis. New York: CRC Press, 345-376, https://doi.org/10.1201/b12437.

Bovaird, T., Löffler, E., eds. (2003): Public Management and Governance. London: Routhledge, https://doi.org /10.4324/9780203634219.

Bovaird, T. (2007): Beyond engagement and participation: User and community coproduction of public services. Public Administration Review 67(5), 846-860, https:// doi.org/10.1111/j.1540-6210.2007.00773.x.

Ermini, B., SantolinI, R. (2010): Local expenditure interaction in Italian municipalities: Do local council partnerships make a difference?. Local Government Studies 36(5), 655-677, https://doi.org/10.1080 /03003930.2010.506979.

Fukuyama, F. (2013): What is governance?. Governance 26(3), 347-368, https://doi.org/10.1111/gove.12035.

Getimis, P., Magnier, A. (2013): Municipal priorities in urban planning and local development. In Egner, B., Sweeting, D., eds.: Local Councillors in Europe. Wiesbaden: Springer VS, 237-253, https://doi.org/10.1007 /978-3-658-01857-3.

Gregory, D. et al., eds. (2009): The Dictionary of Human Geography. Singapore: John Wiley\&Sons.

Hampl, M. (1996): Hierarchie systému osídlení a administrativní členění České republiky. GeografieSborník ČGS 101(4), 201-210.

Hampl, M., Ježek, J., Kühnl, K. (1978): Sociálně geografická rajonizace ČSR. Praha: Čs. demografická společnost.

Hána, D., Hellebrandová, L. (2018): Spatial and sectoral differentiation of support to innovative companies from EU funds in Czechia. European Planning Studies 26(8), 1598-1615, https://doi.org/10.1080/09654313 .2018 .1485135 .

Hemmings, P. (2006): Improving Public-spending Efficiency in Czech Regions and Municipalities. OECD Economics Department Working Papers 499, https://doi.org/10 $.1787 / 18151973$.

Hendl, J. (2008): Kvalitativní výzkum: Základní teorie, metody a aplikace. Praha: Portál.

Jüptner, P. et al. (2014): Local Governance between Democracy and Efficiency. Novo mesto: Faculty of Organization Studies.

Kalb, A., Geys, B., Heinemann, F. (2011): Value for money? German local government efficiency in a comparative perspective. Applied Economics 44(2), 201-218, https://doi.org/10.1080/00036846.2010.50211.

Kostelecký, T., Patočková, V., Vobecká, J. (2007): Kraje v České republice - existují souvislosti mezi ekonomickým rozvojem, sociálním kapitálem a výkonem krajských vlád?. Sociologický časopis 43(5), 911-943.

Kuhlmann, S. (2010). Performance Measurement in European local governments: a comparative analysis of reform experiences in Great Britain, France, Sweden and Germany. International Review of Administrative Sciences 76(2), 331-345, https://doi.org/10.1177 /0020852310372050.

Lankina, T., Hudalla, A., Wollmann, H. (2008): Local governance in central and eastern europe: Comparing 
performance in the Czech Republic, Hungary, Poland and Russia. New York: Palgrave Macmillan.

Lynn, L. E., Heinrich, C. J., Hill, C. J. (2000): Studying Governance and Public Management: Challenges and prospects. Journal of Public Administration Research and Theory 10(2), 233-262.

Ministry of Labour and Social Affairs (2006): Analýza sociálně vyloučených romských lokalit a absorpční kapacity subjektů působících v této oblasti, [Online]. Available: https://www.mpsv.cz/documents/20142 /225517/Analyza_romskych_lokalit.pdf/92e483dd -42f4-69f1-0970-9e77318bee97.

Ministry of Labour and Social Affairs (2015): Analýza sociálně vyloučených lokalit v ČR, [Online]. Available: https://www.esfcr.cz/documents/21802/791224 /Analýza+sociálně+vyloučených+lokalit+v+ČR/65125f 3c-3cd9-4591-882b-fd3935458464.

Ministry for Regional Development (2017): Zásady urbánní politiky, [Online]. Available: https://www.mmr.cz /getmedia/37311a0c-57c6-4076-a8ad-e5d0beede942 /Zasady-urbanni-politiky-aktualizace-2017.pdf.

Ministry for Regional Development (2020): Seznam operací (List of Operations), [Online]. Available: https:// dotaceeu.cz/cs/statistiky-a-analyzy/seznamy -prijemcu.

Ministry of the Interior (2019): Výroční zpráva o stavu veřejné správy v $\check{C} R$ v roce 2018 , [Online]. Available: https://www.mvcr.cz/clanek/vystupy-strategickeho -ramce-rozvoje-verejne-spravy.aspx?q=Y2hudW09 NA\%3d\%3d.

Nekola, M. (2004): Politická participace a efektivita vládnutí. In Kabele, J. et al. (eds). Rozvoj české společnosti v Evropské unii. Praha: Matfyzpress, 322-340.
Plaček, M. et al. (2016): Political business cycle in the Czech Republic: case of municipalities. Prague Economic Papers 3, 304-320, https://doi.org/10.18267/j.pep.566.

Potůček, M. et al. (2005): Veřejná politika. Praha: Sociologické nakladatelství.

Rumpel, P., Slach, O. (2012): Governance of shrinkage of the city of Ostrava. Praha: European Science and Art Publishing.

Rumpel, P., Slach O., Koutný, J. (2013): Shrinking cities and governance of economic reneration: the case of Ostrava. E\&M Economics and Management 16(2), 113-128.

Silva, C. N., Buček, J., eds. (2017): Local Government and Urban Governance in Europe. Springer International Publishing, https://doi.org/10.1007 /978-3-319-43979-2.

Sisk, T. D., ed. (2001): Democracy at the local level: The international IDEA handbook on participation, reperesentation, conflict management, and governance. Stockholm: International IDEA.

Swianiewicz, P., ed. (2010): Territorial consolidation reforms in Europe. Budapest: Open Society Institute.

Št’astná, L., Gregor, M. (2011): Local government efficiency: Evidence from the Czech municipalities. Praha: IES FSV UK, http://dx.doi.org/10.2139/ssrn.1978730.

Worthington, W., Dollery, B. (2000): An empirical survey of frontier efficiency measurement techniques in local government. Local Government Studies 26(2), 23-52, https://doi.org/10.1080/03003930008433988

Zdražil, P. (2019): Změny ve struktuře výdajů českých municipalit. In Klímová, V., Žítek, V. (eds.): XXII. mezinárodní kolokvium o regionálních vědách. Sborník př́ispěvků. Brno: Masarykova univerzita, https://dx.doi.org/10.5817/CZ.MUNI.P210-9268 $-2019-47$.

Appendix 1 Overview of strategic and development documents of analyzed cities.

\begin{tabular}{|c|c|c|c|}
\hline City & Strategic document & City & Strategic document \\
\hline \multirow{6}{*}{ Děčín } & Strategic development plan of the city Děčín (2001) & \multirow{6}{*}{ Sokolov } & Strategic plan for sustainable development of the city \\
\hline & Strategic development plan of the city Děčín (2004) & & $\begin{array}{l}\text { Development plan of social services of Sokolov city } \\
\text { for the period 2009-2013 }\end{array}$ \\
\hline & II. Strategic plan of the city Děčín (2013) & & $\begin{array}{l}\text { Development plan of social services of Sokolov city } \\
\text { for the period 2014-2018 }\end{array}$ \\
\hline & Strategic development plan of the city Děčín 2014-2020 & & $\begin{array}{l}\text { Strategic plan of social inclusion of Sokolov for the period } \\
2017-2019\end{array}$ \\
\hline & $\begin{array}{l}\text { I. community plan of social services of the city Děčín } \\
\text { 2006-2008 }\end{array}$ & & $\begin{array}{l}\text { Strategic plan of local partnership in Sokolov for the period } \\
2014-2016\end{array}$ \\
\hline & $\begin{array}{l}\text { II. community plan of social services of the city Děčín } \\
\text { 2010-2013 }\end{array}$ & & \\
\hline \multirow{5}{*}{ Chomutov } & The city development framework strategy 2014-2024 & \multirow{5}{*}{ Most } & $\begin{array}{l}\text { Strategic development plan of the city Most by } 2020 \\
(2016-2020)\end{array}$ \\
\hline & Community plan of social services & & $\begin{array}{l}\text { Integrated plan of city development: "Deprived city area } \\
\text { and civic coexistence" }\end{array}$ \\
\hline & $\begin{array}{l}\text { Social policy of the city Chomutov with a focus on social } \\
\text { Inclusion 2013-2015 }\end{array}$ & & $\begin{array}{l}\text { Integrated plan of city development Most: Housing estate } \\
\text { Liščí Vrch and Výsluní }\end{array}$ \\
\hline & $\begin{array}{l}\text { A long-term plan for the development of education and } \\
\text { promoting employment in the Chomutov city by } 2020\end{array}$ & & $\begin{array}{l}\text { III. community plan of social services of the city Most } \\
\text { 2015-2018 }\end{array}$ \\
\hline & $\begin{array}{l}\text { Integrated plan of city development: "Area of the } \\
\text { former barracks and the surrounding area" }\end{array}$ & & $\begin{array}{l}\text { Strategic plan of local partnership in Most for the period } \\
\text { 2013-2014 }\end{array}$ \\
\hline
\end{tabular}

Source: Strategic documents provided upon request under Act No. 106/1999 Coll., on free access to information, websites of the town of Děčín, Chomutov, Most, and Sokolov. 